\title{
Prediction of mortality rate of trauma patients in emergency room at Cipto Mangunkusumo Hospital by several scoring systems
}

\author{
Pande M.W. Tirtayasa, Benny Philippi \\ Department of Surgery, Faculty of Medicine, Universitas Indonesia, Cipto Mangunkusumo Hospital, Jakarta, Indonesia
}

\begin{abstract}
Abstrak
Latar belakang: Penanganan trauma dikenal sebagai salah satu tantangan utama pada pelayanan kesehatan saat ini. Sistem skor trauma yang mudah digunakan dapat memberi informasi pada dokter mengenai tingkat keparahan pasien dan membantu dalam pengambilan keputusan mengenai tatalaksana pasien berikutnya. Penelitian ini bertujuan untuk menentukan sistem skor trauma yang paling sesuai dengan membandingkan prediksi angka mortalitas menggunakan sistem skor: 1) triage-revised trauma score (T-RTS); 2)mekanisme, Glasgow coma scale (GCS), umur, dan tekanan arteri (MGAP); 3) dan GCS, umur, dan tekanan darah sistolik (GAP) pada pasien trauma di Instalasi Gawat Darurat (IGD) Rumah Sakit Cipto Mangunkusumo (RSCM).
\end{abstract}

Metode: Penelitian dilakukan secara retrospektif menggunakan data status pasien dengan trauma yang datang ke ruang resusitasi IGD RSCM sepanjang tahun 2011. Sebanyak 185 pasien trauma ditangani di ruang resusitasi IGD RSCM. Kriteria inklusi adalah semua pasien trauma yang langsung datang atau dibawa ke ruang resusitasi IGD RSCM. Kriteria eksklusi adalah pasien rujukan dari rumah sakit lain dan semua pasien trauma anak ( $<18$ tahun). Data dasar pasien dihitung berdasarkan masing-masing trauma skor. Luaran (pasien hidup atau meninggal) dicatat dalam 24 jam pertama sejak masuk rumah sakit.

Hasil: Sebanyak 124 kasus dianalisis dengan rerata usia 32,4 tahun dan angka kesudahan meninggal sebanyak 23 (18,5\%) kasus. Angka mortalitas kelompok risiko rendah pada system skor T-RTS, MGAP, dan GAP berturut-turut sebesar 5\%,1,3\%, dan 1,4\% ( $p=1,000)$. Angka mortalitas kelompok risiko sedang pada sistem skor T-RTS, MGAP, dan GAP berturut-turut sebesar 39,4\%, 32,1\%, dan 36,3\% ( $p=0,841)$. Angka mortalitas kelompok risiko tinggi pada system skor T-RTS, MGAP, dan GAP berturut-turut sebesar 100\%, 72,2\%, dan 85,7\% ( $p=0,782)$.

Kesimpulan: Tidak ada perbedaan bermakna pada sistem skor T-RTS, MGAP, dan GAP dalam memprediksi mortalitas. Sistem skor T-RTS paling sesuai karena tidak membedakan kelompok umur dan mekanisme trauma pasien. (Med J Indones. 2013;22:227-31. doi: 10.13181/mji.v22i4.603)

\begin{abstract}
Background: Trauma management is well recognized as one of the main challenges in modern health care. Easy-touse trauma scoring systems inform physicians of the severity of trauma and help them to decide the course of trauma management. The aim of this study was to find the most applicable trauma scoring system which can be used by physicians by comparing prediction of the mortality rate using: 1)triage-revised trauma score (T-RTS); 2) mechanism, Glasgow coma scale (GCS), age, and arterial pressure (MGAP); and GCS, age, and systolic blood pressure (GAP) scoring system on trauma patients in emergency room (ER) at Cipto Mangunkusumo Hospital.

Methods: The data were collected retrospectively from medical records of trauma patients who came to the resuscitation area in ER at Cipto Mangunkusumo Hospital throughout 2011. As many as 185 patients were managed. The inclusion criteria were all trauma patients who came to the resuscitation area in ER. All referred patients, patients under eighteen, and uncompleted data were excluded. The data were calculated based on each scoring system. The outcome (death or alive) was collected on first 24 hours following admission.

Results: There were 124 cases analyzed, with mean of age of 32.4 years and total mortality rate up to 23 cases (18.5\%). The mortality rate of low risk group on T-RTS, MGAP, and GAP was $5 \%, 1.3 \%$, and $1.4 \%$ respectively $(\mathrm{p}=1.000)$. The mortality rate of intermediate risk group on T-RTS, MGAP, and GAP was $39.4 \%, 32.1 \%$, and $36.3 \%$, respectively $(\mathrm{p}=0.841)$. Mortality rate of high risk group on T-RTS, MGAP, and GAP was $100 \%, 72.2 \%$, and $85.7 \%$ respectively $(\mathrm{p}=0.782)$.

Conclusion: There was no difference on T-RTS, MGAP, and GAP scoring system in predicting mortality rate. T-RTS is the most applicable trauma scoring system since it does not differ the age and mechanism of trauma. (Med J Indones. 2013;22:227-31. doi: 10.13181/mji.v22i4.603)
\end{abstract}

Keywords: GAP, MGAP, T-RTS, Trauma scoring system

Trauma is a time-sensitive condition and well recognized as one of the main challenges in modern health care. ${ }^{1-4}$ Easy-to-use trauma scoring systems inform physicians of the severity of the trauma in patients and help them to decide the course of trauma management. ${ }^{5}$ The use of trauma scoring systems is appropriate in two situations that occur in trauma patient care. ${ }^{1}$ They can be used in the field, before the patient reaches the hospital, to decide whether or not to send the patient to a trauma center. ${ }^{6}$ They can also be used for clinical decision making when the trauma patient has just arrived at the emergency room (ER). ${ }^{7,8}$ 
When the patient is in the ER, trauma scoring systems can be used to prepare the patient for surgery. ${ }^{1}$

Several trauma scoring systems have been already used. One of them was the easy-to-assess triagerevised trauma score (T-RTS). ${ }^{1}$ T-RTS used three specific physiologic parameters, Glasgow coma scale (GCS), blood pressure and respiration rate. ${ }^{1,9,10}$

Another simple trauma scoring system was reported by Sartorius, et $\mathrm{al}^{11}$ They introduced the mechanism, Glasgow coma scale, age and arterial pressure (MGAP) scoring system as improvement of previous trauma scoring systems. ${ }^{11,12}$ Kondo, et $\mathrm{al}^{1}$ introduced the latest trauma scoring system which was the modification of MGAP trauma scoring system. They modified MGAP to Glasgow coma scale, age, and systolic blood pressure (GAP). ${ }^{1}$ Kondo, et al ${ }^{1}$ claimed that their trauma scoring system can predict in-hospital mortality more accurately than the previously developed trauma scoring systems.

The aim of this study was to find the most applicable trauma scoring system which can be used by physicians by comparing the prediction of mortality rate of T-RTS, MGAP and GAP scoring systems on trauma patients.

\section{METHODS}

The data were collected retrospectively from medical records of trauma patients who came to the resuscitation area in ER at Cipto Mangunkusumo Hospital during the year of 2011. The inclusion criteria was all trauma patients with low risk to high risk who came to the resuscitation area in ER at Cipto Mangunkusumo Hospital. All referred patients, patients under eighteen years old, and uncompleted data were excluded. The basic data of patients was calculated based on each scoring system as seen on table 1 . The outcome, dead or alive was collected on first 24 hours following admission.

The data were classified into three risk groups as follows: low risk $(\mathrm{T}-\mathrm{RTS}=11-12$; $\mathrm{MGAP}=19-24$; GAP $=19-24)$, intermediate risk $($ T-RTS $=8-10$; MGAP $=18-22$; GAP $=11-18)$, and high risk $($ T-RTS $<8$; MGAP $<18$; GAP $<11$ ). This classification was based on previous studies. ${ }^{1,11}$

Mortality rate of every risk group on T-RTS, MGAP and GAP scoring systems were subjected to analysis. For statistical analysis, Kolmogorov-Smirnov and chi-square tests were used, since the data involved 3 groups, non-related, and categorical type. Computation was done using SPSS statistics 16.0 software; $p$ value $<0.05$ were considered statistically significant.

\section{RESULTS}

Throughout 2011, 185 trauma patients were managed but only 124 patients satistied selection criteria.

Table 1. Presentation of variables on each trauma scoring system

\begin{tabular}{|c|c|c|c|c|c|}
\hline \multicolumn{2}{|c|}{ T-RTS } & \multicolumn{2}{|c|}{ MGAP } & \multicolumn{2}{|c|}{ GAP } \\
\hline \multicolumn{2}{|c|}{ Systolic blood pressure $(\mathrm{mmHg})$} & \multicolumn{2}{|c|}{ Systolic blood pressure $(\mathrm{mmHg})$} & \multicolumn{2}{|c|}{ Systolic blood pressure $(\mathrm{mmHg})$} \\
\hline$>89$ & 4 & $>120$ & 5 & $>120$ & 6 \\
\hline $76-89$ & 3 & $60-120$ & 3 & $60-120$ & 4 \\
\hline $50-75$ & 2 & $<60$ & 0 & & \\
\hline $1-49$ & 1 & & & & \\
\hline 0 & 0 & & & & \\
\hline \multicolumn{2}{|c|}{ Respiratory rate (minute) } & \multicolumn{2}{|c|}{ Mechanism of trauma } & \multicolumn{2}{|c|}{ Age (year) } \\
\hline $10-29$ & 4 & Blunt trauma & 4 & $<60$ & 3 \\
\hline$>29$ & 3 & & & & \\
\hline $6-9$ & 2 & & & & \\
\hline $1-5$ & 1 & & & & \\
\hline 0 & 0 & & & & \\
\hline \multicolumn{2}{|c|}{ Glasgow coma scale } & \multicolumn{2}{|c|}{ Age (year) } & \multicolumn{2}{|c|}{ Glasgow coma scale } \\
\hline $13-15$ & 4 & \multirow[t]{5}{*}{$<60$} & \multirow[t]{5}{*}{5} & \multirow[t]{5}{*}{ GCS } & $*$ \\
\hline $9-12$ & 3 & & & & \\
\hline $6-8$ & 2 & & & & \\
\hline $4-5$ & 1 & & & & \\
\hline 3 & 0 & & & & \\
\hline \multicolumn{6}{|c|}{ Glasgow coma scale } \\
\hline \multirow{2}{*}{\multicolumn{6}{|c|}{ GCS $*$}} \\
\hline & & & & & \\
\hline \multicolumn{2}{|c|}{$0-12$} & \multicolumn{2}{|c|}{$3-29$} & \multicolumn{2}{|c|}{$3-24$} \\
\hline
\end{tabular}

T-RTS = triage-revised trauma score; MGAP = mechanism, glasgow coma scale, age, and arterial pressure; $\mathrm{GAP}=$ Glasgow coma scale, age, and arterial pressure; * GCS value 
Demographic, mortality rate, mechanism of trauma, and site of injury data can be seen on table 2 .

There were 124 cases analyzed with mean of age (range) of 32.4 (19-70) years and total mortality rate up to $18.5 \%$ (23 cases). One hundred cases

Table 2. Demographic, mortality-rate, mechanism of trauma, and site of injury distribution

\begin{tabular}{lc}
\hline \multicolumn{1}{c}{ Variabel } & $\mathrm{n}(\%)$ \\
\hline Sex & \\
Male & $103(83.1 \%)$ \\
Female & $21(16.9 \%)$ \\
Mean age (range), years & $32.4(19-70)$ \\
Mortality rate & \\
Alive & $101(81.5 \%)$ \\
Dead & $23(18.5 \%)$ \\
Mechanism of trauma & $100(80.6 \%)$ \\
Blunt trauma & $24(19.4 \%)$ \\
Penetrating trauma & \\
Site of injury & $74(59.7 \%)$ \\
Head & $18(14.5 \%)$ \\
Thorax & $12(9.7 \%)$ \\
Abdomen & $20(16.1 \%)$ \\
Extremity & 124 \\
Total cases &
\end{tabular}

(80.6\%) with blunt trauma and 24 cases (19.4\%) with penetrating trauma.

The mortality pattern on first 24-hour following admission on each trauma scoring system is shown in table 3 . The comparison of mortality rate on each trauma scoring system can be seen in table 4 .

No statistical analysis showed $p$-value $<0.05$, thus no statistically significance found on T-RTS, MGAP, and GAP scoring system on predicting mortality rate.

\section{DISCUSSION}

Champion, et $\mathrm{a}^{13}$ developed the revised trauma score (RTS) and the T-RTS in 1989 as a revision of the trauma score. ${ }^{12,13}$ The T-RTS is used in the clinical context for triage and clinical decision-making, whereas the RTS is used by researchers and administrators for case mix control and benchmarking. ${ }^{12,13}$

The RTS was developed using the major trauma outcome study (MTOS) database which used over 26,000 subjects. ${ }^{12}$ The RTS uses the weight given by the logistic regression analysis and provides an outcome prediction. ${ }^{12}$ The T-RTS was derived on admission physiology data on 2,166 North American consecutive trauma patients included in a trauma centre database. ${ }^{12}$ Champion, et $\mathrm{al}^{13}$ divided systolic blood pressure and

Table 3. Mortality pattern on first 24 hours following admission

\begin{tabular}{lccc}
\hline Variables & $\begin{array}{c}\text { Alive } \\
\mathrm{n}(\%)\end{array}$ & $\begin{array}{c}\text { Dead } \\
\mathrm{n}(\%)\end{array}$ & $\begin{array}{c}\text { Total } \\
\mathrm{N}\end{array}$ \\
\hline T-RTS & & & \\
$11-12$ (Low risk) & $81(95 \%)$ & $2(5 \%)$ & 83 \\
$8-10$ (Intermediate risk) & $20(60.6 \%)$ & $13(39.4 \%)$ & 33 \\
$<8$ (High risk) & $0(0 \%)$ & $8(100 \%)$ & \\
MGAP & & & 78 \\
$23-29$ (Low risk) & $77(98.7 \%)$ & $1(1.3 \%)$ & 28 \\
$18-22$ (Intermediate risk) & $19(67.9 \%)$ & $9(32.1 \%)$ & 18 \\
$<18$ (High risk) & $5(27.8 \%)$ & $13(72.2 \%)$ & 73 \\
GAP & $72(98.6 \%)$ & $1(1.4 \%)$ & 44 \\
$19-24$ (Low risk) & $28(63.7 \%)$ & $16(36.3 \%)$ & 7 \\
$11-18$ (Intermediate risk) & $1(14.3 \%)$ & $6(85.7 \%)$ & \\
$<11$ (High risk) &
\end{tabular}

Table 4. Comparison of mortality rate on each trauma scoring system

\begin{tabular}{ccccc}
\hline Mortality rate & T-RTS & MGAP & GAP & p \\
\hline Low risk & $2 / 83(2.4 \%)$ & $1 / 78(1.3 \%)$ & $1 / 73(1.4 \%)$ & $1.000^{*}$ \\
Intermediate risk & $13 / 33(39.4 \%)$ & $9 / 28(32.1 \%)$ & $16 / 44(36.3 \%)$ & $0.841^{* *}$ \\
High risk & $8 / 8(100 \%)$ & $13 / 18(72.2 \%)$ & $6 / 7(85.7 \%)$ & $0.782^{*}$ \\
\hline
\end{tabular}

*Kolmogorov-Smirnov; ** chi-square 
respiratory rate into integers that approximated the intervals chosen for GCS since GCS has proven to predict the need for trauma centre admittance. ${ }^{12,14-16}$ The T-RTS is simple to use in trauma centers and reliable indicator of prognosis of polytraumatized patients. ${ }^{12,17-21}$

The MGAP was developed by Sartorius, et a ${ }^{14}$ using 1,360 trauma patients data receiving care from a prehospital mobile intensive care unit in 22 centers in France during 2002. ${ }^{11,12}$ The association of prehospital variables with in-hospital deaths was tested using logistic regression. ${ }^{11,12}$ The MGAP defined as three risk groups as follows: low (23-29 points), intermediate (18-22 points), and high risk $(<18$ points). ${ }^{11,12}$ The mortality rate was $2.8 \%, 15 \%$, and $48 \%$, respectively. ${ }^{11,12}$

The GAP was developed by Kondo, et $\mathrm{al}^{1}$ using data derived from the Japan Trauma Data Bank (JTDB), which consists of 114 major emergency hospitals in Japan. ${ }^{1}$ A total of 35,732 trauma patients were eligible for inclusion in the study and 27,254 patients data were analyzed. ${ }^{1}$ The GAP was a modification of the MGAP. ${ }^{1}$ The GAP defined as three risk groups as follows: low (19-24 points), intermediate (11-18 points), and high risk (3-10 points). ${ }^{1}$ The mortality was $<5 \%$ for low risk and $>50 \%$ for high risk. ${ }^{1}$

Sartorius, et $\mathrm{al}^{11}$ cited that it need to improve the old trauma scoring system into the new one with several considerations. ${ }^{11}$ They observed that respiratory rate provides less information than modern oxygen saturation monitoring in trauma patients, and that it does not add more information to other variables used in old trauma scoring system. ${ }^{11}$ The second consideration was weighting coefficients from the MTOS population used for RTS are probably out of date because of medical progress. ${ }^{11}$

Kondo, et a ${ }^{1}$ assumed that respiratory rate, a component of the T-RTS is less reliable than other factors because it is influenced by patient age, mechanism of injury and mechanical ventilation. ${ }^{1}$ They also cited that MGAP scoring system has problems. ${ }^{1}$ Its mechanism score is doubtful because it gives higher scores for penetrating trauma, which is not always more severe than blunt trauma. ${ }^{1}$ Moreover, the mechanism score based on penetrating trauma usually affects fewer than $10 \%$ of all of trauma patients. ${ }^{1}$

In this study, the mortality rates on low risk on T-RTS, MGAP, and GAP were $5 \%, 1.3 \%$, and $1.4 \%$, respectively. Mortality rate on this study did not differ significantly than that of previous study. Sartorius, et a ${ }^{11}$ reported that mortality rate on low risk on MGAP was $2.8 \% .{ }^{11}$ Mortality rate on low risk in GAP was similar to that of previous study $(<5 \%){ }^{1}$

In this study, the mortality rates on intermediate risk on T-RTS, MGAP, and GAP were $39.4 \%, 32.1 \%$, and $36.3 \%$, respectively, which showed different result from previous study. Sartorius, et $\mathrm{al}^{11}$ reported that mortality rate was $15 \%$ in MGAP whereas $32.1 \%$ in this study. Mortality rate on intermediate risk in GAP was similar to that of previous study $(5-50 \%){ }^{1}$

In this study, the mortality rates on high risk in T-RTS, MGAP, and GAP were $100 \%, 72.2 \%$, and $85.7 \%$, respectively. Our result was different from that of Sartorius, et $\mathrm{al}^{11}$ reported mortality rate of $48 \%$ on MGAP compared to $72.2 \%$ in this study. Our findings in mortality rate on high risk based on GAP was similar to that of previous study $(>50 \%){ }^{1}$

The different result showed in our findings compared to previous studies was due to smaller number of subjects in this study compared to those in previous studies. Secondly, differences in knowledge, ability, and patient management among studies were observed. Recently, resuscitation area in ER at Cipto Mangunkusumo Hospital does not have certain trauma scoring system which can be used quick and precise. Up till now, the hospital is still trying to find the most applicable trauma scoring system.

In a systematic review concerning prognostic models of trauma patients, Rehn, et al ${ }^{12}$ reported that T-RTS and MGAP can predict survival adequately, however the MGAP fulfilled most of suggested methodological quality items and is recommendable for routine use. Kondo, et $\mathrm{al}^{1}$ claimed that GAP score is simpler, more generalizable and a better predictor of in-hospital mortality than previous trauma scores.

Our study showed that mortality rate on T-RTS, MGAP, and GAP were not significantly different on each risk group (low, intermediate, and high). Out of these three scoring systems, the most applicable scoring system in ER at Cipto Mangunkusumo Hospital was the T-RTS since T-RTS did not use age on its variable. Mean patients age who came to the ER at Cipto Mangunkusumo Hospital was 32.4 years. Only a small number of old patients with trauma came to the ER. Second, T-RTS did not differ between mechanism of trauma (blunt vs penetrating). We believe that we do not need to differentiate between blunt trauma and penetrating trauma since patients with penetrating trauma are not always on worse condition as compared to patients with blunt trauma. 
There was no significant difference on T-RTS, MGAP, and GAP scoring system in predicting mortality rate when applied on trauma patients who came to the resuscitation area in ER at Cipto Mangunkusumo Hospital. T-RTS is the most applicable trauma scoring system in ER at Cipto Mangunkusumo Hospital since it does not differ the age and mechanism of trauma of the patients.

\section{REFERENCES}

1. Kondo Y, Abe T, Kohshi K, Tokuda Y, Cook EF, Kukita I. Revised trauma scoring system to predict in-hospital mortality in the emergency department: Glasgow Coma Scale, Age, and Systolic Blood Pressure score. Crit Care. 2011;15(4):R191.

2. Larsen KT, Uleberg O, Skogvoll E. Differences in trauma team activation criteria among Norwegian hospitals. Scand J Trauma Resusc Emerg Med. 2010;18:21.

3. Cameron PA, Gabbe BJ, Cooper DJ, Walker T, Judson $\mathrm{R}$, McNeil J. A statewide system of trauma care in Victoria: effect on patient survival. Med J Aust. 2008;189(10):546-50.

4. Sasser SM, Hunt RC, Sullivent EE, Wald MM, Mitchko J, Jurkovich GJ, et al. Guidelines for field triage of injured patients: recommendations of the national expert panel on field triage. MMWR Recomm Rep. 2009;58:1-35.

5. Lefering R. Development and validation of the revised injurity severity classification score for severely injured patients. Eur J Trauma Emerg Surg. 2009;35(5):437-47.

6. Lehmann R, Brounts L, Lesperance K, Eckert M, Casey L, Beekley A, et al. A simplified set of trauma triage criteria to safely reduce overtriage: a prospective study. Arch Surg. 2009;144(9):853-8.

7. Dehli T, Fredriksen K, Osbakk SA, Bartness K. Evaluation of a university hospital trauma team activation protocol. Scand J Trauma Resusc Emerg Med. 2011;19:18.

8. MacKenzie EJ, Rivara FP, Jurkovich GJ, Nathens AB, Frey KP, Egleston BL, et al. A national evaluation of the effect of trauma-center care on mortality. N Engl J Med. 2006;354(4):366-78.
9. Chawda MN, Hildebrand F, Pape HC, Giannoudis PV. Predicting outcome after multiple trauma: which scoring system? Injury. 2004;35(4):347-58.

10. Lefering R. Trauma score systems for quality assessment. Eur J Trauma. 2002;28(2):52-63.

11. Sartorius D, Manach YL, David JS, Rancurel E, Smail N, Thicoipe M, et al. Mechanism, glasgow coma scale, age, and arterial pressure (MGAP): a new simple prehospital triage score to predict mortality in trauma patients. Crit Care Med. 2010;38(3):831-7.

12. Rehn M, Perel P, Blackhall K, Lossius HM. Prognostic models for the early care of trauma patients: a systematic review. Scand J Trauma Resusc Emerg Med. 2011;19:17.

13. Champion HR, Sacco WJ, Copes WS, Gann DS, Gennarelli TA, Flanagan ME. A revision of the trauma score. J Trauma. 1989;29(5):623-9.

14. Norwood SH, McAuley CE, Berne JD, Vallina VL, Creath RG, McLarty J. A prehospital glasgow coma scale score < or $=14$ accurately predicts the need for full trauma team activation and patient hospitalization after motor vehicle collisions. J Trauma. 2002;53(3):503-7.

15. Crossman J, Bankes M, Bhan A, Crockard HA. The glasgow coma score: reliable evidence? Injury. 1998;29(6):435-7.

16. Rowley G, Fielding K. Reliability and accuracy of the Glasgow Coma Scale with experienced and inexperienced users. Lancet. 1991;337(8740):535-8.

17. Fizuhri SB, Philippi B. Alat prognostik kematian akibat trauma (GCS, RTS, TRISS) di kamar resusitasi: studi pendahuluan di IGD RSUPN Cipto Mangunkusumo. J I Bedah Indonesia. 2002;30(3):101-5. Indonesian.

18. Champion HR. Trauma Scoring. Scandinavian Journal of Surgery. 2002;91:12-22.

19. Ahmad HN. Evaluation of revised trauma score in polytraumatized patients. J Coll Physicians Surg Pak. 2004;14(5):286-9.

20. Moore L, Lavole A, Abdous B, LeSage N, Liberman M, Bergeron E, et al. Unification of the revised trauma score. J Trauma. 2006;61(3):718-22.

21. Senkowski CK, McKenney MG. Trauma scoring systems: a review. J Am Coll Surg. 1999;189(5):491-503. 